\title{
1. Introduction: the process of institutionalised European integration and the permissive consensus of the first four decades
}

The European Union can today look back to a period of gradual institutional integration which spans more than six decades. The process had its origins in the immediate period after the end of the Second World War, a global military conflict that had managed to exceed the horrors and destruction of its predecessor. The six countries (France, Germany, Italy, Belgium, Luxembourg and the Netherlands) that embarked on the pooling of their national economic sovereignty in the European Coal and Steel Community (ECSC) established in 1952 clearly had more farreaching intentions in the long run. The treaty establishing the ECSC explicitly stated that the sectoral integration of national economic sectors among the six would only be the first step towards the 'foundation of a broad and independent community among peoples divided by bloody conflicts; and to lay the bases of institutions capable of giving direction to their future common destiny' (European Council 1952, preamble). French Foreign Minister Robert Schuman spoke openly of the ambition to develop the Community into 'a European federation, indispensable to the preservation of peace' (Schuman 1950). Schuman worked closely with Jean Monnet, the founding father of the ECSC who subsequently became the president of its High Authority, the precursor of the European Commission. Monnet persistently advocated the vision of creating a united federal Europe which would be based on common rules and supranational institutions. What became known as the Monnet method of integration emphasised the need for all countries involved in the process of institutionalised integration in Europe to accept the transfer of sovereignty to common institutions and to abide by common rules. Monnet was convinced that in order for the European project to work in practice there could be no opt outs from the rules and the acceptance of supranational institutional authority: 
Six countries started by combining their resources ... to do this, they established rules that were the same for all and common institutions to which the United States and national parliaments granted an authority delegation. This method is quite new. It leads to community decisions thanks to a permanent dialogue between the European Commission and a Council where the national governments are seated. (Monnet 1965)

The six countries subsequently followed Monnet's vision when they created the European Economic Community (EEC) under the Treaty of Rome in 1957. The EEC became associated with the ECSC and the newly created Euratom, which supervised the integration of nuclear energy sectors among the six. Legally, however, the three communities remained separate and were only referred to collectively as the European Community after institutional merger of the three Councils in 1967. The newly founded organisation clearly had far-reaching goals in the determination of the ambition to 'lay the foundations of an ever-closer union among the peoples of Europe' (European Commission 1957). The gradual elimination of national trade barriers and the implementation of the four freedoms of movement for people, goods, services and capital were the basis for the creation of the Common European Market. The main aim of the Common Market lay in 'progressively approximating the economic policies of Member States' and achieving the 'harmonious development of economic activities' (ibid., Article 2). This reflected the functionalist perspective at the heart of the process of institutionalised European integration. The notion was that sectoral economic integration would be the basis for gradual full economic integration between member states in the form of a borderless Common Market. The founding fathers of the EEC assumed that economic integration would have to be accompanied by the process of spill-over of political authority from the national level towards the supranational European institutions. Neofunctionalist scholars prominently provided the conceptual background for this vision by introducing the concept of spill-over into the academic debate. The founding father of the school, Ernst B. Haas, and subsequently Philippe C. Schmitter, considered the emerging European integration process as one where the functional spill-over of powers towards the new European centre would result in the growing identification of national political elites, stakeholders and ultimately also citizens with supranational institutions and policies, which in practice meant political spill-over (Haas 1968, p. 317). The neofunctionalist assumption that the integration process would result in the inevitable political socialisation of national elites with the effect of the increasing convergence of national interests became the basis for how Community representatives like Monnet expected the organisation to work. In this context neofunctionalists in fact showed little concern for the European 
integration project lacking direct input legitimacy through public participation in the decision-making process:

Integration and its dynamics could be sustained by a predominantly utilitarian (interest-fulfilling) rather than affective/identitive (emotional) support by the constituent publics - i.e., an abstract, non-politicized, passive and outputoriented 'permissive consensus'. (Chryssochoou 2009, p. 30)

In his later writings Haas had to revise his assumption that the integration process would follow a linear progression from sectoral economic towards full political integration. Haas now acknowledged that linear integration with high levels of functional spill-over towards 'de facto or de jure political union is difficult to identify and hazardous to predict' and was most likely to occur in the area of market integration. In other areas he observed the tendency for elite decision-makers to engage in the 'selfencapsulation' of the integrative progress that was made in a particular policy area (Haas 1970, p. 615). Most importantly, however, Haas admitted that the functional spill-over, which occurs as part of the European integration process, is not permanent and can be reversed if the economic or political benefits from deeper integration fail to materialise (ibid., p. 617). This reinforced the notion that in practice European integration manifested itself as a utilitarian process without the profound emotional attachment of elite decision-makers to a strategic vision based on a joint European vocation. Political spill-over in the form of the socialisation of national elites and the general public towards a joint European spirit therefore remained markedly limited. Haas underlined this by characterising the negotiations between national government representatives in the Council as 'incremental, subdued, and unemotional' and orientated towards 'reciprocity of benefits, unanimous agreement, and package deals among issue areas' (ibid., p. 618). More than a decade after the signing of the Treaty of Rome he also detected the distinctive disjointing between the EC's institutional level and national/regional politics (ibid., p. 617). Schmitter supported Haas in this assessment when he measured the early neofunctionalist theory against real developments. Schmitter emphasised that the neofunctionalist hypothesis, which assumed that national strategic interests would eventually be replaced by 'transnational coalitions' and that the autonomy of nation states would gradually be eroded by the spill-over of sovereignty towards the Community level had failed to manifest itself in practice. Instead he admitted that the integration process continued to strongly depend on the assessment of national actors who adjust their attitude towards deeper integration on the basis of domestic circumstances (Schmitter 1970, pp. 855-6). 
In practice Monnet and the political leaders of the six founding members showed little concern for the establishment of mechanisms which would allow the public to participate directly in Community-level decisionmaking. The Monnet method of supranational policy-making considered Community-level governance as a process which should be reserved to the expertise of elite-level actors., The binding collective decisions made by national governments in the Council were supposed to be legitimised by the electoral mandate they obtain in national elections. The focus on the interests of political and economic elites resulted in a governance method where these elites effectively shut out direct public engagement and even limited the influence of national parliaments (Wallace and Reh 2015, pp. 99-100). The Treaty of Rome determined that the EEC's decision-making process would have to be conducted through the interaction between the national governments represented in the Council, the European Commission as the Community's administrative body and what was then called the Assembly, with the term European Parliament appearing in brackets (European Commission 1957, article 4). Although elections were envisaged in the treaty, article 137 of the treaty specified that the Assembly would not consist of directly elected representatives but of national delegates selected by each national parliament until proposals for 'direct universal suffrage' were determined (ibid., article 137). The Assembly (European Parliament) did not have its first direct democratic election until June 1979. For the subsequent 22 years the European Community operated on the basis of the Monnet integration method which assumed that citizens would be content with restricting their influence on Community-level decisions to periodic national parliamentary elections. The 'permissive consensus' under which the public gave indirect consent to elite-level bargains behind closed doors was the predominant feature of the European Community (Hooghe and Marks 2009, p. 5). This is in line with Schmitter's definition of legitimacy as essentially a process where the public grants power to governing elites on the basis of the strong trust in their responsibility:

Legitimacy is a shared expectation amongst actors in an arrangement of asymmetric power such that the actions of those who rule are accepted voluntarily by those who are ruled because the latter are convinced that the actions of the former conform to pre-established norms. (Schmitter 2001, p. 2)

In this respect Vivian Schmidt has made an important differentiation regarding the $\mathrm{EC} / \mathrm{EU}$ legitimacy upon which the permissive consensus in the EC/EU was based. Schmidt characterises the EC, and the EU as its successor under the Maastricht Treaty, as a regional state whose legitimacy is predominantly output-orientated with some periodic consultation 
of national stakeholder interests, but with clearly limited opportunity for direct public participation ('input democracy') (Schmidt 2006, p. 4). During the first four decades of the European integration process, citizens accepted very limited direct participation in the EU-level policy-making process, which was grounded in the expectation that EC/EU elites would govern in the interest of the wider public. The result of the EC/EU having been perceived as an organisation of 'policies without politics' (Schmidt 2006, p. 5) has been the persistent public focus on the domestic politics and the parallel lack of engagement with the details of Community-level political bargaining and decision-making.

The traditional emphasis of the integration process on output legitimacy manifested itself in relatively high levels of public trust in the ability of elite-level decision-making to result in effective common policy solutions, which were expected to improve personal and collective security and living conditions in the long run. The first Eurobarometer survey the EC published in July 1974 showed overwhelming support for the deepening of economic and political integration among the now nine member states (including the UK, Ireland and Denmark after the first enlargement in the previous year). Across the nine EC countries, 74 per cent of citizens considered the scope of the Common Market integration to be insufficient at this stage (European Commission 1974, pp. 13-14). Table 1.1 shows that a clear majority of the public in all member states supported more joint action on the Community level when they were asked if important problems were more likely to be solved by all member states acting together or by individual national action.

This was even more pronounced when citizens were asked about strategic individual policy areas; in each case a clear majority stated that the

Table 1.1 Action by all members within the Community or independent action by each member state (\%)

\begin{tabular}{lccccc}
\hline & The 'Six' & Ireland & Denmark & Gr. Brit. & Community \\
\hline Joint action & 78 & 80 & 59 & 57 & 73 \\
Independent action & 10 & 16 & 19 & 30 & 14 \\
No reply & 12 & 4 & 22 & 13 & 13 \\
TOTAL & 100 & 100 & 100 & 100 & 100 \\
\hline
\end{tabular}

Note: In Germany, France, Italy, Luxembourg and Ireland $80 \%$ of those interviewed favoured joint action; the figure was slightly lower in Belgium (73\%) and the Netherlands $(70 \%)$ and fell to a little below $60 \%$ in Denmark and Great Britain.

Source: European Commission (1974), p. 16. 
Table 1.2 Assessment of Community action for the two problems which will become the most important

\begin{tabular}{lcccc}
\hline & \multicolumn{2}{c}{ Community action is } & \multirow{2}{*}{ No reply } & Total \\
\cline { 2 - 3 } & Sufficient & Not sufficient & & \\
\hline Rising prices & 7 & 76 & 17 & 100 \\
Energy & 13 & 69 & 18 & 100 \\
Protection of nature & 10 & 74 & 16 & 100 \\
Consumer protection & 7 & 75 & 18 & 100 \\
Political unity & 11 & 73 & 16 & 100 \\
European currency & 12 & 70 & 18 & 100 \\
Differences between regions & 13 & 70 & 17 & 100 \\
Jobs, vocational training & 11 & 73 & 16 & 100 \\
Agriculture & 14 & 60 & 16 & 100 \\
Equivalence of qualifications & 10 & 71 & 19 & 100 \\
Aid to under-developed countries & 12 & 72 & 16 & 100 \\
Scientific research & 15 & 68 & 17 & 100 \\
None of these problems & 2 & 16 & 82 & 100 \\
TOTAL (1) & 10 & 72 & 18 & 100 \\
\hline
\end{tabular}

Note: (1) Unweighted total of national samples.

Source: European Commission (1974), p. 14.

Community's state of play was insufficient. The public even supported enhanced Community action in policy areas such as monetary policy and 'political unity', which tend to be controversial as they directly affect the sovereign autonomy of nation states (Table 1.2).

The trend of growing public support for determining supranational solutions and deepening political integration continued throughout the 1980s and up until the early 1990s. The EC had witnessed its second enlargement in the early 1980s, this time towards Southern Europe. In the Eurobarometer conducted on the occasion of the 30th anniversary of the Treaty of Rome in 1987, the Community of the now 12 member states (including Greece, Spain and Portugal) still showed an overall positive trend towards the EC and support for deeper integration. The March 1987 Eurobarometer recorded rising support among the citizens of the original six member states for EC membership. The number of citizens in the founding members (EC-6), who considered membership a benefit increased from 60 per cent in 1984 to 65 per cent in 1987. In the EC-12 the figure only stood at 53 per cent, with 38 per cent disagreeing (European Commission 1987, pp. 5-6). It was therefore obvious that the enlargement of the EC had brought in 


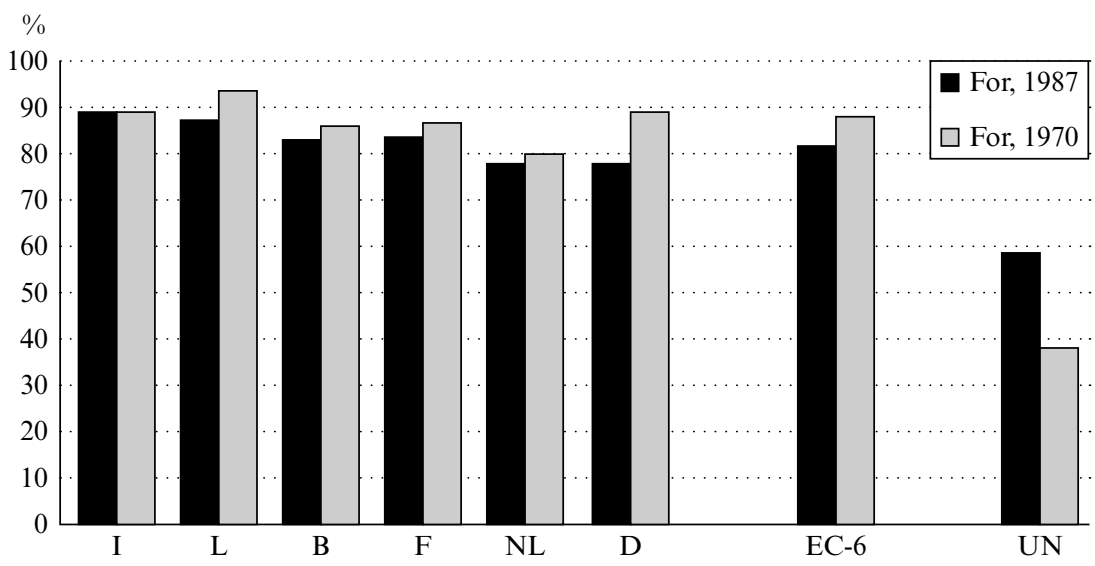

Source: European Commission (1987), p. 27.

Figure 1.1 'For' the EC developing towards a United States of Europe (percentage of those who replied, 1970 and 1987)

new member states, such as the United Kingdom and Denmark, who were less enthusiastic about the integration project. At the same strong public support for moving the EC towards political union that was recorded in the 1970s was starting to weaken slightly. The March 1987 Eurobarometer recorded lower levels of public support in most member states than 17 years previously for developing the EC towards the 'United States of Europe' with full political union. The most noticeable decline in support was in Germany, and the least pronounced was in Italy (Figure 1.1).

Overall support for full political integration nevertheless remained very high. In this respect the Eurobarometer analysis points out that while the UK remained below the EC average when it came to support for deepening integration, the percentage of British public support for a 'United States of Europe' had increased from 30 per cent in 1970 to 52 per cent in 1987. The Eurobarometer conclusion was hence that 'the British disclose an impressive, steady evolution towards clearly "pro European" positions'. This was remarkable given the hostility of large parts of the UK's tabloid media and the Thatcher government's eurosceptic attitude in the 1980s. Simultaneously, the slight decline in support for deeper integration among the EC-6 founding members, most of all in West Germany, seemed to be the effect of disillusionment with the slow and limited progress the Community had made towards deepening integration since its foundation in 1957 (European Commission 1987, p. 28). 
Table 1.3 The role of the new European Parliament (\%)

\begin{tabular}{lrrrrrrrrrr}
\hline & B & DK & D & F & IRL & I & L & NL & UK & EC \\
\hline More important role & 28 & 24 & 30 & 32 & 37 & 56 & 53 & 40 & 31 & 36 \\
Less important role & 7 & 10 & 19 & 3 & 5 & 2 & 4 & 7 & 6 & 8 \\
About the same & 36 & 44 & 31 & 33 & 48 & 22 & 33 & 38 & 47 & 34 \\
Don't know & 29 & 22 & 20 & 32 & 10 & 20 & 20 & 15 & 16 & 22 \\
TOTAL & 100 & 100 & 100 & 100 & 100 & 100 & 100 & 100 & 100 & 100 \\
\hline
\end{tabular}

Source: European Commission (1979), p. 19.

The relatively strong levels of public support for deepening supranational institutional integration remained limited when it came to the European Parliament. Even when the Assembly was transformed into a parliament with directly elected representatives in June 1979, public interest remained limited. The Eurobarometer poll conducted in the wake of the first European Parliament (EP) elections in December 1979 recorded significant levels of scepticism towards the role of the newly elected parliament. Only in Italy and Luxembourg did the majority of citizens consider the direct election of the EP to make a difference in terms of giving it a more important role in the future. In all the other nine member states the majority of citizens either had no opinion on the matter or considered the EP's role to remain the same as before or even less important (Table 1.3).

Very few people across the EC-9 considered that the EP would be very effective in terms of scrutinising other supranational institutions (10 per cent) or help towards speeding up progress towards political union (18 per cent). Where citizens considered the EP to potentially make a difference was in the area of economic cooperation. Here 58 per cent expressed the opinion that the EP would be an initiator of intergovernmental cooperation aimed at tackling economic crisis conditions. Simultaneously concerns that the EP would remain a talking shop were widespread (57 per cent) (European Commission 1979, p. 43). This was reflected in the lack of participation in EP elections. At the first direct election in June 1979 average turnout across all member states stood at 61.99 per cent. Five years later turnout had dropped to 58.9 per cent and declined further with each election to reach the lowest point of 42.6 per cent at the May 2014 election (Figure 1.2).

The low and persistently declining lack of interest in the EP elections is predominantly the result of two factors. First of all, the EP fails to mobilise citizens across the EU to elect representatives as it has never managed to convince voters that it is a relevant institution when it comes to influencing actual policies. Although the powers of the EP to participate in 


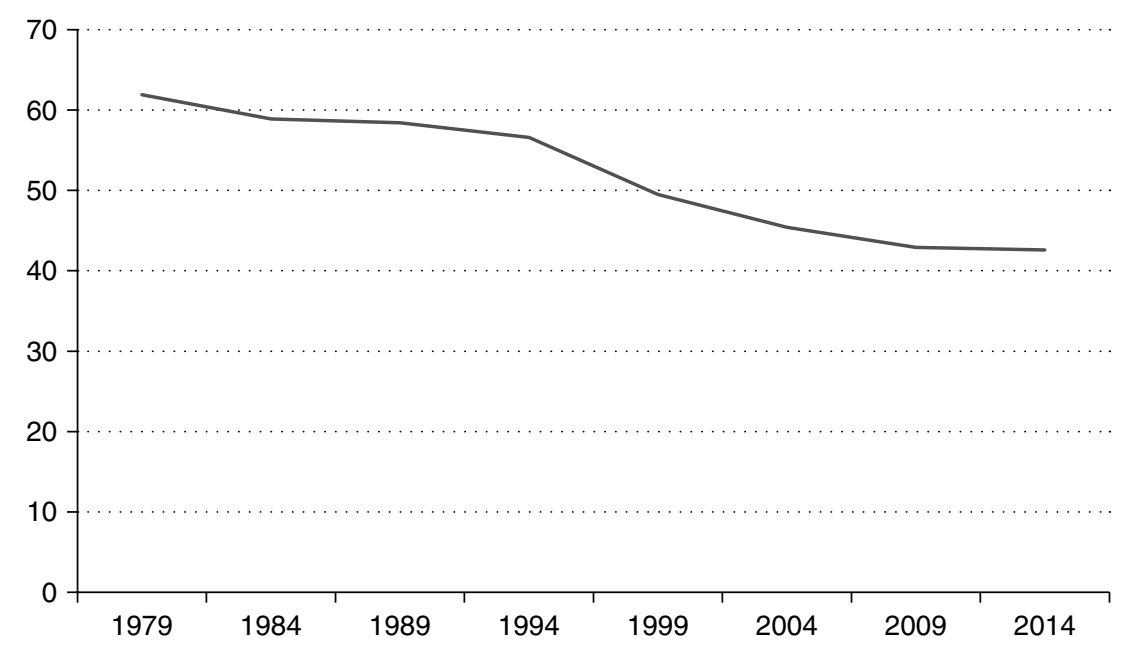

Source: European Parliament, available at http://www.europarl.europa.eu/elections2014results/en/turnout.html (accessed 25 September 2015).

Figure 1.2 Average voter turnout at European Parliament elections, 1979 2014 (\% of registered voters)

the EU's decision-making process have grown substantially over the years, the public has failed to connect with the institution which is supposed to represent their interest in the EU's system of multi-level governance (Lodge 2010, p. 20). This leads directly to the second crucial factor for low turnout, which is the tendency of EP election campaigns to become dominated by national issues. EP elections therefore were always 'second order elections', where candidates and the media tend to focus on national issues and voters who participate tend to support opposition parties in protest against the national government of the day (Hix and Marsh, 2011). The lack of voter identification with the EP's overall purpose and its internal structure, where national parties are submerged into larger but not always internally coherent political groupings (Lightfoot 2010, p. 32 and p. 38), strengthen the second-rate nature of EP elections. This explains why many voters feel inclined to vote for populist or even extremist eurosceptic protest parties in an election they consider as generally irrelevant for national and EU-level policy-making (Hix and Hoyland 2011, p. 149). The prioritisation of output legitimacy under the classic Monnet method of integration resulted in the strong focus on elite-level intergovernmental bargaining and the neglect of the EU's obvious lack 
of input legitimacy. National governments became encapsulated in what Fritz W. Scharpf described as the 'joint decision trap' in the Council, where they were required to reach unanimity in order to be able to make decisions (Scharpf 1988, p. 244). Scharpf emphasised that under the preMaastricht arrangement national governments suffered from the dilemma of having to find unanimous agreement, even if it was not in their interest to do so. The problem with this arrangement was that intergovernmental relations in the Council maintained a bargaining style and failed to be conducted in the spirit of collective solidarity, which is the precondition for a 'problem-solving approach' (ibid., p. 265). Member states failed to undergo a process of joint European socialisation because they lacked 'moral, ideological or idealistic commitment on all sides' (ibid., p. 263). Intergovernmental decisions consequently frequently resulted in zero sum bargains which maintained existing benefits for member states without considering the wider implications for the Community. The joint decision trap hence made new policy and institutional settlements difficult to achieve as the Community presented itself as an institutional arrangement whose policy outcomes have an inherent (non-accidental) tendency to be sub-optimal' (ibid., p. 271). In terms of practical policy-making this manifested itself in the predominance of negative over positive integration. This means that priority was given to the removal of existing national regulations over the pooling of sovereignty to create new supranational policies and institutions. It has been most noticeable in the prioritisation of market liberalisation over political integration (Scharpf 1999). Instead of following the public's desire for the swift advancing of deeper political integration, political elites prioritised the completion of the Common Market (Majone 2005). Over time the idealistic ambitions of the Monnet method hence became lost in the European Community's elitist governance web, which presented itself increasingly as a technocratic and remote exercise to citizens. The more advanced Common Market legislation and the more 'fuzzy' the Community's governance processes became (Schmitter 2001, p.6), the more citizens felt the impact on their daily lives and consequently started to question the lack of input legitimacy in Community-level decisions (Scharpf 2009, p. 21). The dark heart beating inside the historic process of institutionalised integration on the European continent gradually but certainly became exposed.

\section{REFERENCES}

Chryssochoou, Dimitris N. (2009), Theorizing European Integration, 2nd edn, London and New York: Routledge. 
European Commission (1957), 'The Treaty of Rome', 25 March, available at http://ec.europa.eu/archives/emu_history/documents/treaties/rometreaty2.pdf (accessed 23 September 2015).

European Commission (1974), 'Eurobarometer No. 1: April-May 1974', July, available at http://ec.europa.eu/COMMFrontOffice/PublicOpinion/index.cfm/ ResultDoc/download/DocumentKy/62754 (accessed 29 September 2015).

European Commission (1979), 'Eurobarometer: after the election of the European Parliament',No.12,December, availableathttp://ec.europa.eu/COMMFrontOffice/ PublicOpinion/index.cfm/ResultDoc/download/DocumentKy/62785 (accessed 1 October 2015).

European Commission (1987), 'Eurobarometer: public opinion in the European Community 1957-1987', available at http://ec.europa.eu/COMMFrontOffice/ PublicOpinion/index.cfm/ResultDoc/download/DocumentKy/58266 (accessed 30 September 2015).

European Council (1952), 'Treaty Constituting the European Coal and Steel Community', available at http://www.consilium.europa.eu/uedocs/cmsUp load/Treaty $\% 20$ constituting $\% 20$ the $\% 20$ European $\% 20$ Coal $\% 20$ and $\% 20$ Steel $\%$ 20Community.pdf (accessed 21 September 2015).

Haas, Ernst B. (1968), The Uniting of Europe: Political, Social and Economic Forces, 1950-1957, 2nd edn, Stanford, CA: Stanford University Press.

Haas, Ernst B. (1970), 'The study of regional integration: reflections on the joy and anguish of pretheorizing', International Organization, 24 (4), 606-46.

Hix, Simon and Hoyland, Bjorn (2011), The Political System of the European Union, Basingstoke, UK: Palgrave Macmillan.

Hix, Simon and Marsh, Michael (2011), 'Punishment or protest? Understanding European Parliament elections', Electoral Studies, 69 (2), 495-510.

Hooghe, Liesbet and Gary Marks (2009), 'A postfunctionalist theory of European integration: from permissive consensus to constraining dissensus', British Journal of Political Science, 39 (1), 1-23.

Lightfoot, Simon (2010), 'The 2009 European parliamentary elections and the party groups', in Juliet Lodge (ed.), The 2009 Elections to the European Parliament, Basingstoke, UK: Palgrave Macmillan, pp. 30-44.

Lodge, Juliet (2010), 'Irrelevant and obsolete? The European Parliament and voters in perspective', in Juliet Lodge (ed.), The 2009 Elections to the European Parliament, Basingstoke, UK: Palgrave Macmillan, pp. 13-29.

Majone, Giandomenico (2005), Dilemmas of European Integration: The Ambiguities and Pitfalls of Integration by Stealth, Oxford: Oxford University Press.

Monnet, Jean (1965), Speech at the Action Committee Resolution, Berlin, 9 May, quote available at $\mathrm{http}: / /$ www.ajmonnet.eu/index.php?option $=$ com_content\&vi ew $=$ article\&id $=4 \&$ Itemid $=78 \&$ lang $=$ en $($ accessed 21 September 2015).

Scharpf, Fritz W. (1988), 'The joint decision trap: lessons from German federalism and European integration', Public Administration, 66 (Autumn), 239-78.

Scharpf, Fritz W. (1999), Governing in Europe: Effective and Democratic?, Oxford: Oxford University Press.

Scharpf, Fritz W. (2009), 'The asymmetry of European integration or why the EU cannot be a "social market economy", KFG Working Paper Series 6 (September), Kolleg-Forschergruppe (KFG), 'The Transformative Power of Europe', Free University Berlin.

Schmidt, Vivien A. (2006), Democracy in Europe: The EU and National Polities, Oxford: Oxford University Press. 
Schmitter, Philippe C. (1970), 'A revised theory of regional integration', International Organization, 24 (4), 836-68.

Schmitter, Philippe C. (2001), 'What is there to legitimize in the European Union ... and how might this be accomplished?', IHS Political Science Working Paper Series No. 75, available at http://www.eui.eu/Documents/DepartmentsCentres/ SPS/Profiles/Schmitter/LegitimizeEU.pdf (accessed 10 October 2015).

Schuman, Robert (1950), 'TheSchuman declaration',9 May, availableathttp://europa. eu/about-eu/basic-information/symbols/europe-day/schuman-declaration/index en.htm (accessed 21 September 2015).

Wallace, Helen and Christine Reh (2015), 'An institutional anatomy and five policy modes', in Helen Wallace, Mark A. Pollack and Alasdair R. Young (eds), PolicyMaking in the European Union, Oxford: Oxford University Press, pp. 72-114. 